\title{
Efeitos do estresse pelo frio sobre o tamanho nuclear do cardiomiócito em ratos: avaliação por microscopia de luz
}

\author{
Cold stress effects on cardiomyocytes nuclear size in rats: light microscopic evaluation
}

\author{
Adriano MENEGHINI ${ }^{1}$, Celso FERREIRA ${ }^{2}$, Luiz Carlos de ABREU ${ }^{3}$, Marcelo FERREIRA ${ }^{4}$, Celso FERREIRA \\ FILHO $^{5}$, Vitor Engrácia VALENTI ${ }^{6}$, Neif MURAD ${ }^{7}$
}

RBCCV 44205-1028

\section{Resumo}

Introdução: Hipotermia corporal induzida e resfriamento do miocárdio são métodos efetivos em relação à proteção do miocárdio durante cirurgias cardíacas e isquemia. É descrito na literatura que a exposição a temperaturas extremamente baixas causa comprometimentos de miofilamentos e de cristas mitocondriais em cardiomiócitos, entretanto, nenhum estudo analisou os efeitos do estresse pelo frio no tamanho do núcleo dos cardiomiócios.

Objetivos: Analisar os efeitos do estresse agudo pelo frio sobre o tamanho do núcleo dos cardiomiócitos.

Métodos: $\mathrm{O}$ estudo foi realizado em ratos Wistar adultos, pesando 300-310g $(n=20)$. Os ratos foram divididos em dois grupos: 1) Controle (CON) e; 2) Hipotermia induzido (IH). Os animais do grupo IH foram expostos a uma temperatura controlada de $-8^{\circ} \mathrm{C}$, durante 4 horas uma única vez. Foi realizada análise histológica de fígados e glândulas adrenais para examinar a condição de estresse. $O$ tamanho do núcleo dos cardiomiócitos foi examinado por três investigadores independentes com o mesmo critério padronizado e posteriormente analisado pelo coeficiente de correlação de Bartko $(R>0,75=$ concordância positiva $)$. Teste $t$ de Student foi aplicado. $O$ nível de significância foi considerado como $P<0,05$.

Resultados: O grupo exposto ao estresse pelo frio apresentou maior depleção de lipídio nas glândulas adrenais

1. Mestre; Cardiologista. Disciplina de Cardiologia da Faculdade de Medicina do ABC.

2. Professor Titular; Livre Docente; Departamento de Medicina, Disciplina de Cardiologia da Universidade Federal de São Paulo. Disciplina de Cardiologia da Faculdade de Medicina do ABC.

3. Doutor; Professor Assistente. Departamento de Morfologia e Fisiologia da Faculdade de Medicina do ABC.

4. Mestre; Cardiologista. Disciplina de Cardiologia da Faculdade de Medicina do ABC.

5. Doutor; Professor Doutor. Disciplina de Cardiologia da Faculdade de Medicina do ABC.

6. Especialista; Doutorando. Departamento de Medicina, Disciplina de Cardiologia da Universidade Federal de São Paulo. Departamento de Morfologia e Fisiologia da Faculdade de Medicina do ABC.
$(P<0,05)$ e de glicogênio no fígado $(P<0,05)$. O grupo induzido à hipotermia mostrou menor volume do núcleo de seus cardiomiócitos $\left(108+1,7 \mu^{3} ; P<0,05\right)$, reduziu em $76 \%$ comparado ao grupo controle $\left(142+2,3 \mu \mathrm{m}^{3}\right)$. Correlação de Bartko: $\mathrm{CON}=0,44 ; \mathrm{IH}=0,96$, a variação entre a média dos grupos foi significativamente diferente.

Conclusão: Esses resultados sugerem que a exposição ao estresse agudo pelo frio induz redução do núcleo dos cardiomiócitos em ratos.

Descritores: Miócitos cardíacos. Estruturas do núcleo celular. Frio. Estresse.

\section{Abstract}

Introduction: Total body induced hypothermia and myocardial cooling are effective methods regarding myocardial protection during heart surgery and ischemia. It is described in previous studies that extreme low temperature exposure causes mitochondrial cristae and myofilament disarrangement in cardiomyocytes, however, no investigation has analyzed the effects of cold stress on nuclear size of cardiomyocytes.

Objectives: To evaluate the effects of acute cold stress exposure on the nuclear size of cardiomyocytes in rats.

Methods: The experimental study procedures were

7. Doutor; Professor Assistente. Disciplina de Cardiologia da Faculdade de Medicina do ABC

Trabalho realizado na Disciplina de Cardiologia da Faculdade de Medicina do ABC, São Paulo, SP, Brasil.

Endereço para correspondência:

Celso Ferreira

Avenida Príncipe de Gales, 821 - Vila Príncipe de Gales - Santo André, SP - Brasil - CEP 09060-650 - Tel: (11) 4993-5403.

E-mail: celsoferreira.dmed@epm.br

Artigo recebido em 31 de março de 2008 Artigo aprovado em 15 de setembro de 2008 
performed on 300-310g adult male Wistar rats. Rats $(n=20)$ were divided into two groups: 1) Control (CON) and; 2) Induced hypothermic (IH) group. Animals of IH group were exposed during 4 hours once at a controlled temperature of - $8^{\circ} \mathrm{C}$. It was performed histological analysis of liver and adrenal gland to examine the stress condition of animals. Cardiomyocytes nucleus size were examined by three independent investigators with the same and standardized criteria and analyzed by Bartko's intra-class correlation coefficient $(R>0.75=$ positive concordance). Student's t test was applied. The significance level was set at $P<0.05$.

Results: The induced hypothermic group presented higher

\section{INTRODUCTION}

Total body hypothermia and myocardial cooling are considered effective methods for protecting the myocardium during ischemia in heart surgery. However, the protective effect of total body hypothermia and local myocardial cooling before cardioplegia-induced cardiac arrest is somewhat negated by rapid cooling contracture, which results in coronary artery spasm and the subsequent unequal supply of cardioplegic solutions [1].

Induced cold state by low temperature exposure may be considered as an important stressing agent [2]. Consolidated data from the literature point towards the existence of myocardial structural lesions resulting from the exposure of animals to extreme low temperature [3-5]. More frequently, the structural myocardial lesion described is characterized by vacuolization of mitochondrial cristae and myofilament disarrangement [3-5].

Although it is already described by the literature that low temperature exposure causes mitochondrial cristae and myofilament disarrangement in cardiac cells [4], no report has analyzed the effects of cold stress on nuclear size of cardiomyocytes. In view of this consideration, we have addressed the effects of acute cold stress exposure on the nuclear size of cardiomyocytes in rats.

\section{METHODS}

\section{Animals}

Twenty adult male Wistar rats weighing 300-310 grams were used in this study. Temperature was monitored as $22^{\circ} \mathrm{C}$, air humidity nearly $60 \%$ and the clear-dark cycle was controlled and established as twelve hours each one. Animals had free access to food and water. Animals were randomly selected and separated into two groups: 1) Matched control (CON; $n=10)$ and; 2) Induced hypothermic $(\mathrm{IH} ; \mathrm{n}=10)$ : rats exposed to $-8^{\circ} \mathrm{C}$ during four hours once. All procedures were performed in accordance with ethical guidelines of the National Institutes of Health Guide for the Care and Use of Laboratory Animals and were approved lipid depletion in adrenal gland cells $(P<0.05)$ and higher glycogen depletion in liver glycogen $(P<0.05)$. The experimental group showed lower cardiomyocytes nuclear volume $\left(108+1.7 \mu^{3} ; P<0.05\right)$, it decreased in $76 \%$ compared to the control group $\left(142+2.3 \mu \mathrm{m}^{3}\right)$. Bartko's correlation: $\mathrm{CON}=0.44$; $\mathrm{IH}=0.96$, variation analysis between group's means differences was significant.

Conclusion: These data suggest that acute cold stress exposure induces cardiomyocytes nucleus size reduction in rats.

Descriptors: Myocytes, cardiac. Cell nucleus structures. Cold. Stress.

by the Ethical Committee in research of our University (number 1029/06).

\section{Cold Stress Procedure}

Rats were exposed to cold stress by maintaining them at $-8^{\circ} \mathrm{C}$ for 4 hours in a refrigerated compartment in wire mesh cages. Cold stress was performed only once and rats behavior was examined during all the procedures [4].

\section{Histological Procedures}

In order to verify if the exposure to cold stress was able, we evaluated lipid depletion ${ }^{*+++++}$ in adrenal gland cells and glycogen depletion in hepatocytes [4,6]. After adequate level of ether anesthesia, we verified tail tonus and response to external stimuli before and during surgical procedure through evaluation of vibrissa movements, all animals were submitted to a laparotomy. Two pieces of the left liver lobe and right adrenal gland were removed for light microscopy investigation. Fragments were cut into small $1 \mathrm{~mm}^{3}$ pieces and post-fixed in a $1 \% \mathrm{OsO}_{4}$ solution for 2 hours, dehydrated and embedded in araldite. Silver or gray thin sections $(60-90 \mathrm{~nm})$ were selected on a PorterBlum MT-B ultramicrotome. The ultra-slices were mounted on copper silver grids with 200 patches and stained with uranyl acetate and lead citrate.

*+=Small intensity of glycogen or lipid (higher glycogen or lipid depletion); ++++=High intensity of glycogen or lipid (smaller glycogen or lipid depletion) $[4,6]$

\section{Nuclear Volume Measurement}

All animals were submitted to a thoracotomy to remove left ventricle. Fragments of left ventricle material were fixed on alcoholic Bouin and mounted on paraffinand sections measuring 10 micra were stained with hematoxylin-eosin. The Karyometric-statistical method was applied according to the same principle used in a previous publication. To calculate nuclear volume we used the following equation proposed by Salvatore [7]: $\mathrm{V}=(\mathrm{A} 2 \times \mathrm{B}) / 1,91$. $\mathrm{V}=$ volume; $\mathrm{A}=$ smaller axial measure; $\mathrm{B}=$ greater axial measure; $1,91=$ constant. 
Samples were examined by three independent investigators with the same and standardized criteria $[4,7]$.

\section{Statistical Analysis}

Results regarding nuclear cell size are presented as means \pm standard deviation of means, means \pm standard error of means, maximum, minimum, $25 \%, 75 \%$ and median. In order to compare data associated to nuclear cell volume, liver and adrenal histological analysis between the two groups, Student $t$ test was applied. Concordance of measurements performed by the three investigators was analyzed by Bartko's intra-class correlation coefficient according to Fleiss et al. [8] guidelines $(\mathrm{R}>0.75=$ excellent concordance independent of $\mathrm{p}$ value). The significance level was set at $P<0.05$.

Bartko's test formula: $R=N(P M S-E M S) / N(P M S)(K-$ 1) $(R M S)(N-1)(K-1) E M S$

$R=$ Bartkos correlation index; PMS $=$ Patients Mean Square; $R M S=$ Reasearcher Mean Square; $E M S=E r r o r$ Mean Square; $N=$ Number of events; K=Number of investigators

\section{RESULTS}

Immediately after the exposure to cold stress during four hours at $-8^{\circ} \mathrm{C}$, we noted the following behaviors in the induced hypothermic group: bristling hair, edema on paws, tremor, stretch of tail and tachypnea.

Body weights were not statistically different between the two groups (IH-Induced Hypothermic group-306.2 \pm 20.3 vs. CON-Control group-308.6 $\pm 29.7 ; P>0.05$ ). To confirm if the exposure to cold stress was efficient we examined lipid depletion $(\mathrm{CON}=+++v s$. $\mathrm{IH}=+$ ) in adrenal gland cortical cells (data not shown) and glycogen depletion ( $\mathrm{CON}=++++$ vs. $\mathrm{IH}=+$ ) in hepatocytes (data not shown) of the both groups. The IH group presented higher lipid depletion in adrenal gland cells $(P<0.05)$ and higher glycogen depletion in hepatocytes $(P<0.05)$, it supports that the exposure to $8^{\circ} \mathrm{C}$ during four hours was a stressing agent.

To clarify whether the exposure to a cold stress situation promotes cardiomyocytes nuclear size decrease, we performed an evaluation study in two groups. Comparison between CON and IH groups were performed (Table 1). The exposure to cold stress during four hours reduced nuclear size of cardiomyocytes $(P<0.05)$. The nuclear size of the IH group (Table 1 ) decreased in approximately $76 \%$ compared to the CON group (Table 1 ). Data variance analysis by Bartko's correlation index ranged between 0.44-0.96 in the both groups depicts the methodology validation. In addition, variation analysis between group's means differences was statistically significant $(P<0.05)$.
Table 1. Statistical analysis of cardiomyocyte nuclear size of induced hypothermic and control groups.

\begin{tabular}{lcc}
\hline & IH & CON \\
\hline Number of measures & 200 & 200 \\
Minimum & 59.2 & 55.1 \\
$25 \%$ & 89.7 & 55.1 \\
Median & 104.1 & 136.9 \\
Mean & 108.3 & 141.9 \\
$75 \%$ & 123.7 & 158.7 \\
Maximum & 195 & 274.6 \\
Standard Deviation & 25 & 32.2 \\
Standard Error & 1.8 & 2.3 \\
\hline
\end{tabular}

IH-Induced Hypothermic group; CON-Control group

\section{DISCUSSION}

The dramatic improvements in the outcome of heart surgery in recent years have been largely due to the result of advances in methods of myocardial protection. Such methods include widely used hypothermia and local myocardial cooling, which protect the myocardium by lowering myocardial metabolism during ischemia, thus preserving high energy phosphorylated compounds [1]. In this research, we aimed to verify if the acute exposure to $-8^{\circ} \mathrm{C}$ during four hours causes any change in cardiomyocytes nuclear size of rats. Our data noticed that rats exposed to an acute cold stress condition presented reduced cardiomyocytes nuclear size compared to the control group. This information is helpful, since important information should be considered in methods used for protecting the myocardium during ischemia in heart surgery.

It was suggested that the body go through a stress condition during rapid cooling of the heart in cases of total body hypothermia, process used in heart surgery during myocardium ischemia [1]. It is known that any type of stress causes disruption of homeostasis and an imbalanced antioxidant status in several organs [9]. In this study we used cold as an acute stressing agent, considering that when exposed for long term (more than 1 month) it is observed an adaptation mechanism [10-12]. According to Janský et al. [13], the chronic exposure to extreme low temperatures would not decrease cardiomyocytes nuclear size such as we found in our study due to the adjustment condition. Based on our data, we believe that the acute hypothermic exposure causes opposite effects compared to the chronic exposure to cold. These findings are supported by Murad [14], which also used the same model of stress situation and related increase in mitochondrial cristoysis, and suggested an oxidative stress condition in rats exposed to acute cold stress.

Although we used cold as a stress agent in this study, 
induced hypothermia is also used during heart surgery procedures. A hypothermic cardiac arrest offers the possibility of survival because of the effects of rapid cooling. Hypothermia causes a decrease in cellular oxygen demand, which is advantageous during periods of ischemia [15]. Cardiac surgeons take advantage of controlled hypothermia to perform surgery under circulatory arrest. The induced hypothermia has positive and negative points; Wypij et al. [16] evaluated the negative effects of hypothermic cardiopulmonary bypass in infant heart surgery, Eggum et al. [17] noted that only minor differences in cytokine levels were detected between those with moderate and those with mild hypothermia during cardiopulmonary bypass. Moreover, cold agglutinins are predominately immunoglobulin $\mathrm{M}$ autoantibodies that react at cold temperatures with surface antigens on the red blood cell. This can lead to hemagglutination at low temperatures, followed by complement fixation and subsequent hemolysis on rewarming. This autoimmune phenomenon is of unique relevance during cardiac operations when hypothermic cardiopulmonary bypass and cardioplegia are instituted [18]. Our findings may be considered as a negative effect of induced hypothermia, given that it caused reduction of the nuclear size of the cardiac cells.

In summary, our results are the first to indicate that an acute cold stress situation induces cardiomyocyte nuclear size reduction in rats.

\section{REFERENCES}

1. Inoue K, Ando S, Gyuan F, Takaba T. A study of the myocardial protective effect of rapid cooling based on intracellular Ca, intracellular pH, and HSP70. Ann Thorac Cardiovasc Surg. 2003;9(5):301-6.

2. Hasegawa H, Takatori T, Komura T, Yamasaki M. Combined effects of pre-cooling and water ingestion on thermoregulation and physical capacity during exercise in a hot environment. $\mathrm{J}$ Sports Sci. 2006;24(1):3-9.

3. Jatene FB, Nicolau JC, Hueb AC, Atik FA, Barafiole LM, Murta CB, et al. Fatores prognósticos da revascularização na fase aguda do infarto agudo do miocárdio. Rev Bras Cir Cardiovasc. 2001;16(3):195-202.

4. Póvoa R, Bombing MT, Luna Filho B, Simões M, Costa A, Murad N, et al. Myocardial protection against cold stress with pravastatin. Rev Port Cardiol. 1998;17(10):803-7.

5. Monteiro R, Jatene FB, Pazetti R, Correia AT, Manoel LA, Bernardo WM, et al. Avaliação das alterações morfológicas cardíacas secundárias ao enfisema pulmonar: estudo experimental em ratos. Rev Bras Cir Cardiovasc. 2004;19(4):341-7.
6. Bombig MT, Luna Filho B, Costa EA, Leite DA, Póvoa R, Murad N, et al. Effect of verapamil on left ventricular hypertrophy induced by isoproterenol. Arq Bras Cardiol. 1996;67(2):81-5.

7. Salvatore CA. A cytological examination of uterine growth during the estrous cycle and artifically induced estrus. Rev Bras Biol. 1948;8:505-23.

8. Fleiss JL, Spitzer RL, Cohen J, Endicott J. Three computer diagnosis methods compared. Arch Gen Psychiatry. 1972;27(5):643-9.

9. Sahin E, Gümüslü S. Stress-dependent induction of protein oxidation, lipid peroxidation and anti-oxidants in peripheral tissues of rats: comparison of three stress models (immobilization, cold and immobilization-cold). Clin Exp Pharmacol Physiol. 2007;34(5-6):425-31.

10. Rowland T, Hagenbuch S, Pober D, Garrison A. Exercise tolerance and thermoregulatory responses during cycling in boys and men. Med Sci Sports Exerc. 2008;40(2):282-7.

11. Rodnick KJ, Sidell BD. Structural and biochemical analyses of cardiac ventricular enlargement in cold-acclimated striped bass. Am J Physiol. 1997;273(1 Pt 2):R252-8.

12. Rodnick KJ, Sidell BD. Cold acclimation increases carnitine palmitoyltransferase I activity in oxidative muscle of striped bass. Am J Physiol. 1994;266(2 Pt 2):R405-12.

13. Janský L, Vybíral S, Trubacová M, Okrouhlík J. Modulation of adrenergic receptors and adrenergic functions in cold adapted humans. Eur J Appl Physiol. 2008;104(2):131-5.

14. Murad N. Efeito da hidralazina sobre os cardiomiócitos: estudo experimental em ratos albinos [Tese de Mestrado]. São Paulo:Universidade Federal de São Paulo, Escola Paulista de Medicina;1992. 123p.

15. Alam HB, Rhee P, Honma K, Chen H, Ayuste EC, Lin T, et al. Does the rate of rewarming from profound hypothermic arrest influence the outcome in a swine model of lethal hemorrhage? J Trauma. 2006;60(1):134-46.

16. Wypij D, Jonas RA, Bellinger DC, Del Nido PJ, Mayer JE Jr, Bacha EA, et al. The effect of hematocrit during hypothermic cardiopulmonary bypass in infant heart surgery: results from the combined Boston hematocrit trials. J Thorac Cardiovasc Surg. 2008;135(2): 355-60.

17. Eggum R, Ueland T, Mollnes TE, Videm V, Aukrust P, Fiane $A E$, et al. Effect of perfusion temperature on the inflammatory response during pediatric cardiac surgery. Ann Thorac Surg. 2008;85(2):611-7.

18. Atkinson VP, Soeding P, Horne G, Tatoulis J. Cold agglutinins in cardiac surgery: management of myocardial protection and cardiopulmonary bypass. Ann Thorac Surg. 2008;85(1):310-1. 